\title{
Ability of Trichoderma hamatum Isolated from Plastics-Polluted Environments to Attack Petroleum-Based, Synthetic Polymer Films
}

\author{
Kateřina Malachová ${ }^{1, *(1)}$, Čeněk Novotný ${ }^{1,2, *(\mathbb{D})}$, Grażyna Adamus ${ }^{3}\left(\mathbb{0}\right.$, Nadia Lotti $^{4}(\mathbb{D}$, \\ Zuzana Rybková $^{1}$, Michelina Soccio ${ }^{4}\left(\mathbb{D}\right.$, Pavlína Šlosarčíková ${ }^{1}$, Vincent Verney ${ }^{5}(\mathbb{D}$ and \\ Fabio Fava ${ }^{4}$ \\ 1 Department of Biology and Ecology, Faculty of Science, University of Ostrava, Chittussiho 10, 71000 Ostrava, \\ Czech Republic; zuzana.rybkova@osu.cz (Z.R.); PolinkaS@seznam.cz (P.Š.) \\ 2 Laboratory of Environmental Biotechnology, Institute of Microbiology of Czech Acad. Sci., 10000 Prague, \\ Czech Republic \\ 3 Centre of Polymer and Carbon Materials Polish Academy of Sciences, 41-800 Zabrze, Poland; \\ gadamus@cmpw-pan.edu.pl \\ 4 Department of Civil, Chemical, Environmental and Materials Engineering, University of Bologna, \\ 40126 Bologna, Italy; nadia.lotti@unibo.it (N.L.); michelina.soccio@unibo.it (M.S.); fabio.fava@unibo.it (F.F.) \\ 5 Institut de Chimie de Clermont Ferrand, Université Blaise Pascal, Ecole Nationale Supérieure de Chimie, \\ CNRS UMR6296, 63170 Aubière, France; vincent.verney@uca.fr \\ * Correspondence: katerina.malachova@osu.cz (K.M.); novotny@biomed.cas.cz (Č.N.); \\ Tel.: +420-5970-92315 (K.M.); +420-2964-42767 (Č.N.)
}

Received: 31 March 2020; Accepted: 13 April 2020; Published: 16 April 2020

\begin{abstract}
Microorganisms colonizing plastic waste material collected in composting-, landfill-, and anaerobic digestion plants were isolated to obtain novel strains maximally adapted to the degradation of plastics due to long-term contact with plastic polymers. Twenty-six bacterial strains were isolated and identified by the $16 \mathrm{~S}$ rRNA method, and eighteen strains of yeasts and fungi using $18 \mathrm{~S}$ rRNA and the internal transcribed spacer ITS sequencing of the $18 \mathrm{~S}$ rRNA gene. In selected strains, the ability to degrade linear low-density polyethylene (LLDPE), low-density polyethylene (LDPE), polystyrene (PS), and polyvinyl chloride (PVC) was tested in aerobic liquid-medium cultures. An oxidative, two-step pretreatment of LLDPE and LDPE using $\gamma$ - or UV-irradiation followed by a high-temperature treatment was carried out, and the pretreated plastics were also included in the degradation experiments. The respective weight losses after biodegradation by Trichoderma hamatum were: virgin and $\gamma / \mathrm{T} 90$-pretreated LLDPE $(2.2 \pm 1.2$ and $3.9 \pm 0.5 \%)$, virgin and UV/T60-pretreated LDPE $(0.5 \pm 0.4$ and $1.3 \pm 0.4 \%)$, and virgin PS $(0.9 \pm 0.4 \%)$. The Fourier transform infrared spectroscopy (FTIR) analysis showed that during the treatment of pretreated LLDPE, T. hamatum attacked low molecular weight LLDPE oligomers, reducing the functional groups (carbonyl $C=O$ ), which was paralleled by a slight increase of the molar mass of pretreated LLDPE and a decrease of the dispersity index, as demonstrated by gel permeation chromatography (GPC). Thermogravimetric analysis (TGA) highlighted the formation of functional groups on LLDPE due to polymer pretreatment that favored fungal attack at the polymer surface. The results provide insight into microbial consortia that spontaneously colonize the surface of plastics in various environments and their capability to attack plastic polymers.
\end{abstract}

Keywords: bacteria; fungi; screening; plastic-polymer degradation; Trichoderma hamatum 


\section{Introduction}

Research focusing on the biodegradation of recalcitrant plastic polymers brought evidence that many microorganisms are able to attack polymeric chains. However, the degradation efficiency was mostly low [1,2]. Therefore, there is a need to isolate highly degradative strains of bacteria and fungi and better understand the biochemistry of polymer degradation with the aim to develop efficient degradation technologies [3,4]. Polyethylene (PE) is the most common plastic, accounting for $34 \%$ of the total plastics market. It is extremely resistant to biodegradation [1,5]. Its degradability can be enhanced by abiotic photo- and thermooxidative treatments, resulting in the production of carboxyl, hydroxyl, and carbonyl groups that can be oxidized by microbial metabolism [6,7].

PE can be used as the sole carbon source for soil and marine bacteria that generate hydroxyl groups in the polymer [8,9]. Numerous works document the biodegradation potential of fungal organisms towards plastics. The examples include LDPE biodegradation by Aspergillus spp. [10,11], Fusarium spp. [10,12], and Penicillium spp. [13]. An important prerequisite for degradation is an effective contact of the degrading microorganism and its extracellular enzyme machinery with the polymer, ensured by the colonization of the plastic surface with bacterial or fungal biofilms $[2,14]$. Microorganisms are able to modify the hydrophobicity of their cellular surface to promote hydrophobic interactions with the highly hydrophobic polymer surface [15]. The colonization of the polymer surface and the subsequent degradation can be increased by thermal pretreatment, chemical oxidation, or radiation $[16,17]$.

The biodegradation process includes the introduction of functional groups (hydroxyl $-\mathrm{OH}$ and carbonyl $\mathrm{C}=\mathrm{O}$ ) in the polymer molecule and the splitting of the chain by extracellular enzymes to provide small fragments that enter the intracellular metabolism as carbon and energy sources for growth [18]. Peroxidases and laccases are implicated in the degradation of PE, the former reducing the weight average molecular weight and the latter reducing the average molecular weight and average molecular number of the polymer $[19,20]$. Esterases and lipases are involved in degradation of polyester-type polymers [21,22]. A two-step action of bacterial extracellular hydrolases and of a combination of lipase, esterase, and protease activities was also reported in the degradation of the aliphatic-aromatic co-polyester Ecoflex ${ }^{\circledR}[23,24]$.

Microoganisms that are in prolonged contact with plastic wastes are adapted to these environmental conditions to maximize their degradation potential. The strategy for isolating efficient microbial degraders of plastics is often focused on microorganisms colonizing plastic wastes in soil or other plastics-polluted environments $[2,25,26]$. In this study, autochthonous microorganisms colonizing surfaces of plastic wastes from composting plants, landfills, and anaerobic digestion plants were used as a source of novel bacterial and fungal strains, presumably well-adapted to the biodeterioration and biodegradation of plastics. A standard isolation method was used, and the strains were taxonomically classified. Virgin LLDPE and LDPE were subjected to an oxidative pretreatment. Subsequently, both virgin and pretreated LLDPE and LDPE, together with virgin PS and polyvinyl chloride (PVC), were tested for degradation in liquid media with the main purpose of obtaining strains with a high potential of degradation of plastic polymers. The weight reduction data obtained by a treatment of LLDPE by T. hamatum were supported by FTIR and GPC analyses.

\section{Materials and Methods}

\subsection{Isolation and Taxonomical Identification of Bacteria and Fungi from Plastic-Polluted Environments}

Samples of plastic polymers from the following sites were used for the isolation of new bacterial and fungal strains: a compost sample from the municipal composting plant (Grenoble, France), a compost sample from the composting plant (Schendelbeke, Belgium), a sample of black mulching film removed from agricultural soil in Belgium, a plastic sample removed from soil along a highway in Belgium, a sample of sludge from the anaerobic digester at a wastewater treatment plant (Treviso, Italy), and a sample of plastics removed from a landfill (Styron plant, Schkopau, Germany). 
The isolation method employed the following media: Nutrient agar (NA), Boyd Kohlmeyer (BK) medium, Malt extract agar (MEA), Malt extract glucose (MEG) medium, Kirk medium [27], and Bushnell Haas (BH) medium. The media were used for the isolation of bacteria and fungi at $28^{\circ} \mathrm{C}$ from the above environmental samples to obtain monocolony isolates [28]. When fungi were isolated, the medium was supplemented with a penicillin/streptomycin/neomycin solution (Sigma Aldrich, Czech Republic, respective final antibiotic concentrations of 50 units, $0.05 \mathrm{mg} \cdot \mathrm{mL}^{-1}$, and $0.1 \mathrm{mg} \cdot \mathrm{mL}^{-1}$ ) to inhibit the growth of bacteria. The subsequent prescreening of strains was based on the degradation of persistent Azure B dye $\left(100 \mathrm{mg} \cdot \mathrm{L}^{-1}\right)$, which is a method of choice for the rapid evaluation of the capacity of microorganisms to degrade xenobiotics [29-31].

The screened fungi were identified using a sequence analysis of partial $18 \mathrm{~S}$ rRNA and of complete ITS regions of the $18 \mathrm{~S}$ rRNA gene. The bacteria were identified using the partial $16 \mathrm{~S}$ rRNA gene. An amount of $0.5 \mathrm{~g}$ of the samples was used for the isolation of total DNA (soil DNA extraction kit, Sigma-Aldrich, St. Louis, USA), in agreement with the manufacturer's instructions [32]. DNA was analyzed with Nanophotometer P300 (Implen, Munchen, Germany). The amplification of DNA samples was carried out using a bacterial $16 \mathrm{~S}$ primer set [33], universal $18 \mathrm{~S}$ rDNA primer set [34], and fungal specific ITS1/ITS4 primer [35]. The PCR-amplified products were purified and ligated with a pGEM-T easy cloning vector system (Promega, USA) and transformed into OneShot E. coli cells (Invitrogen, Carlsbad, CA, USA) [31,36]. The transformed cells were used for plasmid isolation and purification (Millipore plasmid isolation kit, Millipore, Bedford, USA) [31]. Macrogen Inc. (Amsterdam, Netherlands) sequenced the plasmids. The BLASTN bioinformatics tool was used to obtain the phylogenetic analysis [32]. Alternatively, bacterial isolates were also identified using the BIOLOG system (BIOLOG, Hayward, USA) [37].

\subsection{Plastic Polymers and Their Pretreatment}

LLDPE and LDPE films (density at $20^{\circ} \mathrm{C}: 0.88-0.96 \mathrm{~g} \cdot \mathrm{mL}^{-1}$; thickness: 70 and $40 \mu \mathrm{m}$ for LLDPE and LDPE, respectively) as well as PS (containing traces of a decolorant agent and about $2000 \mathrm{ppm}$ of a release agent) were produced by Versalis S.p.A., Italy. PVC (containing plasticizers whose formulation is confidential) was produced by Gruppo Fabbri Spa., Italy. All plastic polymers were delivered by the Department of Civil, Chemical, Environmental, and Materials Engineering, University of Bologna, Italy. PE films were prepared as a neat formulation of the polymer films, avoiding the use of stabilizers and additives.

The Centre National de la Recherche Scientifique, Clermont-Ferrand, France, performed the pretreatment of LLDPE and LDPE. The materials were submitted to an oxidative pretreatment. The goal of this process was to enhance the hydrophilic character of the studied plastics through hydroxyl and carbonyl chemical groups fixation due to radical oxidation reactions. To ensure going far enough in the oxidative degradation mechanism, new unusual treatments have been set up by cycling different oxidative steps. All these treatments and their conditions have been extensively described in a previous paper [31]. After the treatments, the materials were characterized by FTIR and by melt viscoelasticity to assess the molecular weight evolution [31].

\subsection{Biodegradation Tests}

Aerobic liquid-medium cultures were used to test the capability of microorganisms to degrade plastic polymers. Virgin LLDPE, LDPE, PS, and PVC, as well as pretreated LLDPE and LDPE films, were used in the experiments [38]. The protocol used in the biodegradation experiments with fungal and bacterial strains was the same as that described by Novotny et al. [31]. Small pieces (20-30 mg) of polymer films were used. First, grease was removed from their surface by immersion in $70 \%$ ethanol (10 min., $120 \mathrm{rpm}$ ) which also sterilized the polymers. Then, the plastic films were washed with sterile water, dried, and pre-weighed under sterile conditions to be able to determine the weight reduction at the end of the experiment. The sterilization of all media was made by autoclaving $\left(120^{\circ} \mathrm{C}, 20 \mathrm{~min}\right)$ (Systec VX-5, Systec GmbH, Germany). 
The biodegradation by fungal strains was carried out aseptically in liquid Czapek Dox medium $\mathrm{pH}$ 6.8. After inoculation, the cultures were incubated at $28^{\circ} \mathrm{C}$ and aerated by air diffusion. The fungal static cultures were stirred manually every other day. Fungal cultures grown for seven days in MEG medium (5 g.L $\mathrm{L}^{-1}$ malt extract, $10 \mathrm{~g} \cdot \mathrm{L}^{-1}$ glucose, $\left.\mathrm{pH} 4.5\right)$ were homogenized (Ultra Turrax T25, IKA Labortechnik, Staufen im Breisgau, Germany) and used as 5\% (V/V) inoculum for the above Czapek Dox cultures.

The biodegradation by Bacillus amyloliquefaciens occurred under aseptic conditions in liquid BH medium pH 7.0 (Fluka, Germany), to which $1 \mathrm{~g} \cdot \mathrm{L}^{-1}$ glucose was added. The medium itself did not contain any carbon source and, thus, it was adjusted by adding a small amount of glucose to support the cometabolic process and maintain the bacterial culture viable and active during biodegradation. The aeration was ensured by shaking at $120 \mathrm{rpm}$ using an orbital shaker (ELMI orbital shaker DOS-20 L, ELMI Ltd., Rìga, Latvia). The bacterial inoculum $(5 \%, \mathrm{~V} / \mathrm{V})$ was grown overnight (shaken culture, $28^{\circ} \mathrm{C}$, BK medium $\mathrm{pH} 6.8$ ).

When the biodegradation experiment was terminated, the plastic films were washed (2\% SDS solution, $2 \mathrm{~h})$ to get rid of the attached microbes. Then, they were washed with ethanol $(70 \% \mathrm{~V} / \mathrm{V})$ and deionized water. The degradation was measured as the weight reduction of the dry samples. The samples were measured in triplicates, always including an abiotic control.

\subsection{Physicochemical Analyses}

\subsubsection{FTIR Analysis}

The recording of the infrared spectra of the polymer film samples was as described in [31].

The ATR FTIR spectra of virgin and pretreated LLDPE films obtained before and after the fungal degradation were measured at room temperature [31].

\subsubsection{TGA Analysis}

The analysis conditions are described in detail by Novotny et al. (2018) [31]. The temperature calibration of the equipment followed the protocol suggested by the producer.

\subsubsection{GPC Analysis}

The number average molecular mass $\left(M_{n}\right)$ and molecular mass distribution index $\left(M_{w} / M_{n}\right)$ were measured in 1,2,4-trichlorobenzene containing Santanox-R stabilizer (conditions: $135^{\circ} \mathrm{C}$, flow rate $1 \mathrm{~mL} \cdot \mathrm{min}^{-1}$, Alliance GPCV 2000 chromatograph, HT $(39,500-30,000)$ and HT6E $(5000-1,000,000)$ columns, refractive index- and viscometer detectors), as described by Novotny et al. (2018) [31]. Polystyrene standards with a mass range of 580-3,790,000 were used to obtain the calibration curve. $\mathrm{K}=0.0004$ and $\alpha=0.74$ were used in the calculation [31].

\subsubsection{Scanning Electron Microscopy (SEM)}

The samples (thin slices of a plastic film) were cut into $5 \times 5 \mathrm{~mm}^{2}$ sections with scissors. After slitting, the samples were mounted onto aluminum stubs and gold-coated (Automatic Sputter Coater JEOL JFC-1300, JEOL USA, Inc., coating time 20 s). The samples were scanned using a JEOL JSM-6610LV (Japan) in a high vacuum mode and SEI (secondary electron image). The working distance (WD) was $15 \mathrm{~mm}$, accelerating voltage $12 \mathrm{kV}$, and spot size 30 for all scanned samples. The magnifications used were $500 \times, 2000 \times$, and 5000×.

\section{Results and Discussion}

\subsection{Isolation and Identification of Microorganisms}

New bacterial and fungal strains capable of growth and survival on plastic polymers were isolated from the surface of plastic polymer wastes collected at six environmentally different sites. A total of 
26 bacterial strains were identified using the $16 \mathrm{~S}$ rRNA eubacterial primer set (Table 1). Similarly, 18 fungal strains were identified using $18 \mathrm{~S}$ rRNA and the ITS sequencing of $18 \mathrm{~S}$ rRNA (Table 2). Bacteria of the genus Bacilllus dominated in the compost-, anaerobic sludge- and landfill samples, whereas no similar predominance by a single genus could be observed among the isolated fungal organisms. The prescreening with Azure B based on the strains' decolorization efficiency, evaluated visually on dye-containing agar media (NA) and in liquid medium (BK), was used to select the following strains: the fungal strains Trichoderma hamatum (University of Ostrava collection no. HF4, GenBank accession no. FR87271), Trichaptum abietinum (University of Ostrava collection no. CA, GenBank accession no. J768676), Byssochlamys nivea (University of Ostrava collection no. FK1, GenBank accession no. M83256.1), Byssochlamys nivea (University of Ostrava collection no. JM5, GenBank accession no. GU733368.1), and the bacterial strain B. amyloliquefaciens (University of Ostrava collection no. JB4, GenBank accession no. KT185076). Those strains provided the most efficient and rapid decolorization response and were further tested for the capability to degrade virgin and pretreated LLDPE, LDPE, PS, and PVC. The results obtained with B. amyloliquefaciens JB4 are reported in a parallel paper [31].

Table 1. Bacterial strains isolated from various environments. The strains were identified using BLASTN search with $16 \mathrm{~S}$ rRNA gene sequences, and their GenBank accession nos. of the closest relative are given in brackets.

\begin{tabular}{|c|c|c|}
\hline Environmental Origin & Strain Identity (GenBank Accession No.) & $\begin{array}{l}\text { Q-Coverage, } \\
\% \text { (Error Value) }\end{array}$ \\
\hline \multirow{4}{*}{ Compost (Grenoble, France) } & Vibrio sp. (DQ146981.1) & $99(0)$ \\
\hline & Clostridium roseum (KM999946.1) & $71(0)$ \\
\hline & Bacillus sp. (JX202600.1) & $100(0)$ \\
\hline & Bacillus sp. (KJ162135) & $100(0)$ \\
\hline $\begin{array}{l}\text { Mulching Film From } \\
\text { Soil (Belgium) }\end{array}$ & Pseudomonas poe (JN897284) & $100(0)$ \\
\hline \multirow{2}{*}{$\begin{array}{c}\text { Plastics From Soil Along } \\
\text { Highway (Belgium) }\end{array}$} & Delftia sp. (KF896097) & $100(0)$ \\
\hline & Uncultured Klebsiella sp. (JN873189) & $100(0)$ \\
\hline \multirow{11}{*}{$\begin{array}{c}\text { Compost } \\
\text { (Schendelbeke, Belgium) }\end{array}$} & Achromobacter sp. (KP670417.1) & $100\left(1.00 \times 10^{-112}\right)$ \\
\hline & Vibrio sp. (DQ146981.1) & $99(0)$ \\
\hline & Bacillus licheniformis (KM226937.1) & $97(0)$ \\
\hline & Bacillus amyloliquefaciens JB4 (KT185076) ${ }^{1}$ & $100(0)$ \\
\hline & Bacillus amyloliquefaciens (KJ469792.1) & $100(0)$ \\
\hline & Bacillus amyloliquefaciens (KJ545589) & $100(0)$ \\
\hline & Bacillus amyloliquefaciens (СР006890) & $100(0)$ \\
\hline & Bacillus amyloliquefaciens (CP010556.1) & $99(0)$ \\
\hline & Bacillus pumilus (DQ275671.1) & $97(0)$ \\
\hline & Bacillus subtilis (KJ865584.1) & $100(0)$ \\
\hline & Bacterium ZI-9 (JQ342232.1) & $99(0)$ \\
\hline \multirow{3}{*}{$\begin{array}{l}\text { Sludge From Anaerobic } \\
\text { Digester (Treviso, Italy) }\end{array}$} & Bacillus sp. (СР009938.1) & $100(0)$ \\
\hline & Bacillus sp. (EF582419) & $100(0)$ \\
\hline & Bacillus amyloliquefaciens (KJ545589) & $100(0)$ \\
\hline \multirow{5}{*}{$\begin{array}{l}\text { Plastics From Landfill } \\
\text { (Styron, Germany) }\end{array}$} & Bacillus cereus (KF805048) & $100\left(3.00 \times 10^{-164}\right)$ \\
\hline & Bacillus sp. (FJ596521.1) & $100(0)$ \\
\hline & Bacillus subtilis (KJ604979.1) & $100(0)$ \\
\hline & Klebsiella oxytoca (СР003218) & $100(0)$ \\
\hline & Alcaligenaceae sp. (AB847924.1) & $99(0)$ \\
\hline
\end{tabular}

${ }^{1}$ The strain written in bold was further tested for the capability to degrade various plastic polymers, and the results are reported in a parallel paper [31]. 
Table 2. Fungal strains isolated from various environmental samples. The strains were identified using a BLASTN search with the rRNA gene (18 S sequence, ITS sequence), and their GenBank accession nos. of the closest relative are in brackets.

\begin{tabular}{|c|c|c|c|c|}
\hline \multirow{2}{*}{$\begin{array}{l}\text { Environmental } \\
\text { Origin }\end{array}$} & \multicolumn{2}{|c|}{$18 \mathrm{~S}$ Sequence } & \multicolumn{2}{|l|}{ ITS Sequence } \\
\hline & $\begin{array}{c}\text { Strain Identity } \\
\text { (GenBank Access. No.) }\end{array}$ & $\begin{array}{l}\text { Q-Coverage, \% } \\
\text { (Error Value) }\end{array}$ & $\begin{array}{c}\text { Strain Identity } \\
\text { (GenBank Access. No.) }\end{array}$ & $\begin{array}{l}\text { Q-Coverage. \% } \\
\text { (Error Value) }\end{array}$ \\
\hline $\begin{array}{l}\text { Compost Sample } \\
\text { (Grenoble, France) }\end{array}$ & - & - & Filobasidium floriforme (KF971359) & $100(0)$ \\
\hline \multirow{4}{*}{$\begin{array}{l}\text { Mulching Film } \\
\text { from Soil (Belgium) }\end{array}$} & $\begin{array}{l}\text { Fusarium oxysporum } \\
\text { (KF562839) }\end{array}$ & $100(0)$ & Fusarium oxysporum (JF776163) & $100(0)$ \\
\hline & $\begin{array}{l}\text { Mucor circinelloides } \\
\text { (JQ014009) }\end{array}$ & $100(0)$ & Mucor circinelloides (HQ285608) & $99(0)$ \\
\hline & $\begin{array}{l}\text { Fusarium oxysporum } \\
\text { (KF562839) }\end{array}$ & $100(0)$ & Fusarium oxysporum (KC202938) & $100(0)$ \\
\hline & Trametes sp. (FJ515315) & $99(0)$ & Uncultured Fungus (KF800596) & $100(0)$ \\
\hline \multirow{3}{*}{$\begin{array}{l}\text { Plastics from Soil } \\
\text { Along Highway } \\
\text { (Belgium) }\end{array}$} & $\begin{array}{l}\text { Uncultured fungus } \\
\qquad(\mathrm{AB} 534505)\end{array}$ & $100(0)$ & Fusarium sp. (JQ388248) & $100(0)$ \\
\hline & $\begin{array}{l}\text { Hypocrea muroiana } \\
\text { (JN941682) }\end{array}$ & $100(0)$ & Trichoderma hamatum $\mathrm{HF}^{1}{ }^{1}$ (FR872741) & $100(0)$ \\
\hline & $\begin{array}{l}\text { Uncultured fungus } \\
\text { (GU306002) }\end{array}$ & $99(0)$ & Thanatephorus cucumeris (FR670341) & $100(0)$ \\
\hline \multirow{9}{*}{$\begin{array}{l}\text { Plastic Samples } \\
\text { from Composting } \\
\text { Plant (Belgium) }\end{array}$} & - & - & Galactomyces geotrichum (DQ683112) & $100(0)$ \\
\hline & $\begin{array}{c}\text { Trichaptum abietinum CA } \\
1 \text { (FJ768676) }\end{array}$ & $100(0)$ & Uncultured fungus (JF721422) & $100(0)$ \\
\hline & $\begin{array}{c}\text { Byssochlamys nivea FK1 }{ }^{1} \\
\text { (M83256.1) }\end{array}$ & $100(0)$ & - & - \\
\hline & $\begin{array}{l}\text { Pseudallescheria sp. } \\
\text { (FN666094.1) }\end{array}$ & $99(0)$ & Pseudallescheria sp. (AY939802.1) & $99(0)$ \\
\hline & - & - & Pseudallescheria boydii (AY213683.1) & $99(0)$ \\
\hline & - & - & Trametes suaveolens (KE573015) & $99(0)$ \\
\hline & Trametes sp. (FJ51531) & $99(0)$ & Trametes gibbosa (KC525203) & $100(0)$ \\
\hline & $\begin{array}{l}\text { Pseudallescheria ellipsoidea } \\
\text { (U43911) }\end{array}$ & $100(0)$ & Scedosporium apiospermum (JN207446) & $100(0)$ \\
\hline & Graphium sp. (FJ176832) & $100(0)$ & - & - \\
\hline $\begin{array}{c}\text { Sludge } \\
\text { (Treviso, Italy) }\end{array}$ & $\begin{array}{c}\text { Byssochlamys nivea JM5 }{ }^{1} \\
\text { (GU733368.1) }\end{array}$ & $99(0)$ & - & - \\
\hline
\end{tabular}

${ }^{1}$ The strains written in bold were further tested for the capability to degrade various plastic polymers (cf. Table 3).

Table 3. Plastic polymer weight reductions obtained with preselected isolates of fungi in two-month biodegradation tests in liquid medium cultures using various synthetic polymers.

\begin{tabular}{|c|c|c|c|c|}
\hline Plastic Polymers & Character of Polymers & Microorganism & Weight Loss (\%) & Abiotic Control (\%) \\
\hline \multirow{2}{*}{ LLDPE } & Virgin & Trichoderma hamatum HF4 & $2.2 \pm 1.2$ & $1.3 \pm 0.8$ \\
\hline & Pretreated $8 / \mathrm{T}_{90}{ }^{1}$ & Trichoderma hamatum HF4 & $3.9 \pm 0.5$ & $0.3 \pm 0.1$ \\
\hline \multirow{3}{*}{ LDPE } & Virgin & Trichoderma hamatum HF4 & $0.5 \pm 0.4$ & $0.2 \pm 0.1$ \\
\hline & Pretreated $\mathrm{\gamma} / \mathrm{T} 150^{1}$ & Trichoderma hamatum $\mathrm{HF} 4$ & $0.9 \pm 0.1$ & $0.2 \pm 0.1$ \\
\hline & Pretreated UV/T60 ${ }^{1}$ & Trichoderma hamatum HF4 & $1.3 \pm 0.4$ & $0.4 \pm 0.1$ \\
\hline PS & Virgin & Trichoderma hamatum $\mathrm{HF} 4$ & $0.9 \pm 0.4$ & $0.4 \pm 0.2$ \\
\hline \multirow{4}{*}{ PVC } & \multirow{4}{*}{ Virgin } & Trichoderma hamatum HF4 & $20.0 \pm 0.5$ & \multirow{4}{*}{$9.9 \pm 2.9$} \\
\hline & & Byssochlamys nivea FK1 & $18.4 \pm 0.7$ & \\
\hline & & Trichaptum abietinum CA & $17.5 \pm 0.7$ & \\
\hline & & Byssochlamys nivea JM5 & $15.5 \pm 0.9$ & \\
\hline
\end{tabular}

\footnotetext{
${ }^{1}$ The plastic polymers were pretreated as follows: LLDPE $\mathrm{\gamma} / \mathrm{T} 90, \mathrm{\gamma}$-irradiation $(200 \mathrm{kGy}) /$ temperature $90{ }^{\circ} \mathrm{C}$; LDPE 8/T150, Y-irradiation (50 kGy)/temperature $150{ }^{\circ} \mathrm{C}$; UV/T60, UV irradiation 7 days/temperature $60^{\circ} \mathrm{C}$.
} 


\subsection{Biodegradation of Polymer Plastic Films Measured by Gravimetric Analysis}

The results of the gravimetric analysis after the degradation experiments are shown in Table 3. T. hamatum exhibited a weight reduction rate of about $4 \%(\mathrm{w} / \mathrm{w})$ with the pretreated LLDPE after two months. The weight reduction obtained in the abiotic control was ten times lower. In the case of virgin and pretreated LDPE, the weight losses obtained with T. hamatum were $0.5 \%-1.3 \%(w / w)$, slightly exceeding the values obtained in the abiotic controls. Compared to the degradation rates obtained with virgin LLDPE and LDPE, the improvement of the biodegradability by the pretreatment of LLDPE and LDPE was rather low (Table 3). The biotic weight losses observed were similar to those reported after a 90-day degradation of $\mathrm{\gamma}$-irradiated LDPE by fungal strains of Paecilomyces, Aspergillus, and Lasiodiplodia [38,39]. Similarly, Briassoulis et al. [6] reported weight reductions of $0.7 \%$ and $6.7 \%(w / w)$ of prooxidants-containing LLDPE-P1 mulching films that were exposed to soil conditions for 19 months. On the other hand, wood- and litter-saprotrophic fungi isolated from lake-floating plastic debris were reported not to be able to degrade PE in the form of PE powder in mineral agar medium [40].

PS was highly resistant to biodegradation by $T$. hamatum, the degradation rate after two months being only $0.9 \%(w / w)$ (Table 3). The extremely low degradability of PS is in agreement with the reports of other authors [41].

By far, the highest degradation rates were obtained with PVC (Table 3). Four different microorganisms were tested, and the weight reductions were in the range of $15 \%$ to $20 \%(w / w)$, whereas the abiotic control showed a weight loss of $9.9 \%(w / w)$. PVC polymer usually contains additives such as stabilizers, plasticizers, and lubricants, sometimes in large quantities of up to $30 \%$ in weight.

The predominant plasticizers used in PVC are phthalic acid esters that are well biodegradable by bacteria and fungi $[42,43]$. In keeping with other studies documenting that these additives are primarily attacked by microorganisms [44] and that their removal is responsible for the weight reduction observed in biodegradation experiments [45], we concluded that the weight reductions observed after the exposure to the fungi shown in Table 3 were probably caused by the removal of the additives. The weight reduction values obtained in our experiments with PVC films (Table 3) were comparable to those measured with PVC cables in landfill simulation experiments [45].

The SEM observations showed that the fungal degradation of PVC by T. abietinum and T. hamatum representing a weight loss of $17.5 \%$ to $20 \%(\mathrm{~W} / \mathrm{W})$ (Table 3) resulted in a smooth surface comparable to that of the abiotic control films (9.9\% weight loss) (Figure 1a,c,d). In comparison, the bacterial degradation by B. amyloliquefaciens (18.3\% weight loss) described by Novotny et al. (2018) [31] produced an uneven surface of the PVC films with intertwined fibrils (Figure 1b). The bacterial and fungal attacks thus seem to have a different character. The cracks in the film after the degradation by T. abietinum indicated that the PVC film became brittle after degradation, suggesting a possible glass transition [44], and its outer layer seemed to peel off as a result of the fungal attack (Figure 1c).

Higher standard deviation values in some degradation experiments (Table 3) probably resulted from small amounts of microbial biofilms that remained attached to the polymer surface after washing. Another factor that also contributed to large standard deviation values was the fragmentation of some plastic polymer films, namely the pretreated LDPE, PS, and PVC, into small pieces during biodegradation. Briassoulis et al. [6] mentioned a similar problem in soil experiments.

\subsection{Biodegradation of Polymer Plastic Films by T. Hamatum Measured by Physicochemical Methods}

\subsubsection{FTIR Analysis}

The pretreated LLDPE film samples obtained by degradation with T. hamatum were analyzed by ATR Fourier transform infrared spectroscopy, and then those spectra were compared, respectively, with the pretreated- and virgin LLDPE that were not subjected to the microorganisms' actions. A relatively strong band with a maximum at $1715 \mathrm{~cm}^{-1}$ corresponding to the stretching vibrations of $\mathrm{C}=\mathrm{O}$ groups was observed in the spectrum of the pretreated LLDPE (Figure 2, line A). It is known that the 
appearance of the carbonyl band in the FTIR spectrum of the pretreated LLDPE sample is associated with the presence of carboxylic acid, aldehyde, ketone, ether, or ester groups which arose during the pretreatment of virgin LLDPE by exposing it to $\gamma$-irradiation (200 KGy doses)/thermal treatment at 90 ${ }^{\circ} \mathrm{C}$ (Figure 2, line A). A further comparison of the FTIR spectra of the pretreated LLDPE film samples before (line A) and after a two-month degradation by T. hamatum (line C) showed noticeable changes in the structure of the samples studied, visualized by a slight decrease in the intensity of the carbonyl band in the spectrum C (Figure 2, line C). In order to express the decrease of the concentration of carbonyl compounds measured by FTIR in the case of the pretreated LLDPE sample after a two-month exposure to T. hamatum (Figure 2, line $\mathrm{C}$ ), the carbonyl index was used, calculated as a ratio between the area of the signal at $1715 \mathrm{~cm}^{-1}$ (related to the $\mathrm{C}=\mathrm{O}$ groups' absorbance region) and the signal at $1470 \mathrm{~cm}^{-1}$ (which was ascribed to the methylene absorption band - $\mathrm{CH} 2$ ).

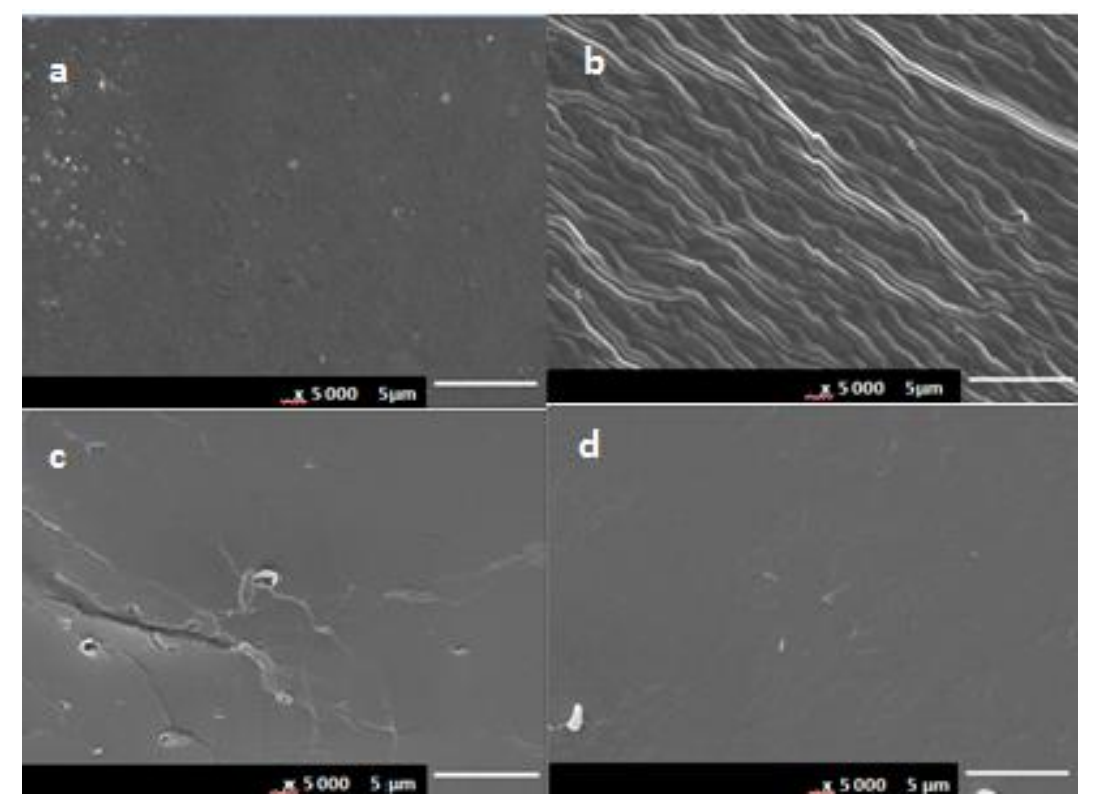

Figure 1. SEM of the PVC surface after a two-month degradation (magnification 5000×): (a) Abiotic control; (b) B. amyloliquefaciens; (c) T. abietinum; and (d) T. hamatum.

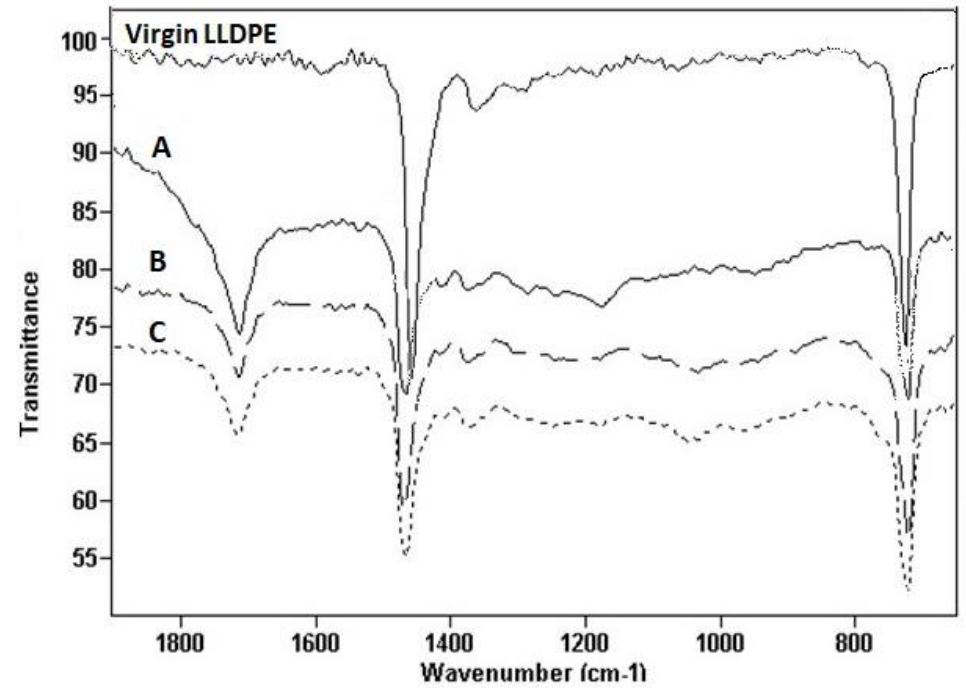

Figure 2. FTIR spectra of pretreated LLDPE after a two-month biodegradation with T. hamatum in liquid medium: Top, virgin LLDPE; (line A), No exposure; (line B), abiotic control (two months); (line C), two-month biodegradation. Pretreatment conditions: $\gamma$-irradiation (200 KGy dose)/thermal treatment $90{ }^{\circ} \mathrm{C}$, seven days. 
The results indicated a slight decrease of the intensity of the $\mathrm{C}=\mathrm{O}$ band in the case of the LLDPE sample analyzed after a two-month exposure to T. hamatum (Figure 2, line $\mathrm{C}$ ) in comparison to the sample collected after the pretreatment (Figure 2, line A) and to the abiotic control (Figure 2, line B). This observation indicated a slight decrease of the quantity of LLDPE oligomers functionalized with carbonyl groups in the sample measured after a two-month exposure to T. hamatum (Figure 2, line C). This effect might be caused by the ability of the fungus to attack and assimilate the $\mathrm{C}=\mathrm{O}$-functionalized, low-molecular-weight LLDPE oligomers, which led to a decrease of the quantity of such oligomers on the film surface of the LLDPE sample studied. A similar effect was observed when the pretreated LLDPE was exposed to B. amyloliquefaciens [31]. A decrease of the carbonyl index was also reported after a 19-month soil burial of pretreated LLDPE-P1 films [6] or after a 2- to 6-week exposure of aged, oxo-biodegradable, pro-oxidant-containing LDPE to Pseudomonas aeruginosa [46].

In the case of the biodegradation of pretreated LDPE (data not shown), the structural differences between the pretreated sample and the sample after a two-month treatment by $T$. hamatum were almost invisible, which indicated a very poor biodegradation ability of this polymer by the microorganism.

\subsubsection{GPC Analysis}

The FTIR results suggesting a microbial attack on functionalized, low-molecular-weight LLDPE oligomers (Figure 2) are in agreement with the measurements of the changes of the average molar masses of pretreated LLDPE samples before and after a two-month biodegradation. The GPC measurements showed that the average molar mass of the virgin LLDPE sample decreased after the $\gamma$-irradiation (200 KGy doses)/thermal treatment of the sample (Table 4, entries 1 and 2). Additionally, the observed higher dispersity index $\mathrm{Mw} / \mathrm{Mn}$ indicated the formation of polymer chains that differed in their lengths, including low-molar-mass oligomers.

Table 4. GPC analysis of virgin- and pretreated LLPDE films exposed or not exposed to T. hamatum.

\begin{tabular}{ccccc}
\hline Polymer & Treatment Conditions & $\mathbf{M}_{\mathbf{n}} \mathbf{( g \cdot \mathbf { m o l } ^ { - \mathbf { 1 } } )}$ & $\mathbf{M}_{\mathbf{w}} \mathbf{( g \cdot \mathbf { m o l } ^ { - \mathbf { 1 } } )}$ & $\mathbf{M}_{\mathbf{w}} / \mathbf{M}_{\mathbf{n}}$ \\
\hline Virgin LLDPE & No exposure & 75,500 & 163,400 & 2.16 \\
\hline Pretreated LLDPE & No exposure & 1900 & 32,200 & 16.9 \\
\hline Pretreated LLDPE & Abiotic control & 2700 & 38,500 & 14.25 \\
\hline Pretreated LLDPE & 60-day exposure & 2700 & 38,000 & 14.07 \\
\hline
\end{tabular}

$\overline{M_{n}}$, number average molecular weight; $M_{w}$, weight average molecular weight; $M_{w} / M_{n}$, polydispersity index. The abiotic control was not exposed to T. hamatum but was incubated for two months in the biodegradation medium under similar conditions.

The molar masses of both the pretreated LLDPE sample after biodegradation and the LLDPE abiotic control sample slightly increased, together with the reduction of the dispersity index (Table 4, entries 3 and 4). Such results can be explained by a migration of water-soluble, low-molar-mass, $\mathrm{C}=\mathrm{O}$-functionalized LLDPE oligomers into the medium or water. Moreover, it is worth emphasizing that in the case of LLDPE samples, after 60 days of exposure to T. hamatum, the dispersity index decreased in comparison with the abiotic control sample. Such a phenomenon can be explained as follows. Due to the presence of the oxygen functional groups (e.g., carbonyl groups) on the surface of the LLDPE film samples, T. hamatum could attack this surface and progressively enhance the biodegradation by the further cleavage of the LLDPE polymer chains and by the formation of an additional amount of low-molar-mass LLDPE oligomers. Both the initial functionalization and the biodegradation process were mostly limited to the surface of the LLDPE film samples. Therefore, O-functional oligomers with a low molar mass, formed both as a result of $\gamma$-irradiation and of the additional two-month action of T. hamatum (due to their greater polarity and greater affinity for the culture medium), could easily be released from the LLDPE film samples into the liquid medium, and could also be assimilated by microorganisms. The migration and/or assimilation of oligomers from the tested LLDPE samples resulted in the loss of low-molecular-weight polymer chains, which 
caused an increase of the molecular homogeneity of the sample, a decrease of the dispersion index $(\mathrm{Mw} / \mathrm{Mn})$, and an increase of the average molar mass of the LLDPE film obtained by the two-month exposure to T. hamatum, as confirmed by the GPC analysis (Table 4, entry 4).

\subsubsection{TGA Analysis}

Figure 3 shows the TGA curves of the pretreated LLDPE films incubated for 20, 40, and 60 days with T. hamatum and the corresponding abiotic controls. For comparison, the curves of the virgin and pretreated LLDPE films are also shown. The pretreatment of LLDPE that included a combined effect of $\gamma$ irradiation and a high temperature caused a huge decrease of the LLDPE thermal stability, which can be ascribed to the formation of functional groups (hydroxylic, carboxylic, etc.), as also evidenced by the FTIR analysis (Figure 3; also cf. Novotný et al. [37]), which accelerated the thermal deterioration. Nevertheless, the formation of functional groups was limited to the LLDPE surface and probably produced low-molecular-weight, polar segments that solubilized in the culture medium. This is evidenced by the abiotic control curves obtained after a 60-day exposure to the culture medium in the absence of T. hamatum, which were very similar to the virgin LLDPE curves. The trend was somewhat different in the presence of the fungus, where the pretreated LLDPE sample incubated for 20 days was the least thermally stable of all the samples. This suggested that the oxidized groups produced by irradiation were preferentially attacked by the fungus, with a further cleavage of polymer chains. This effect was, however, limited to the LLDPE film surface, since the thermal stability of the samples incubated with $T$. hamatum was progressively enhanced with time as the functional groups produced by irradiation were consumed by the fungus.

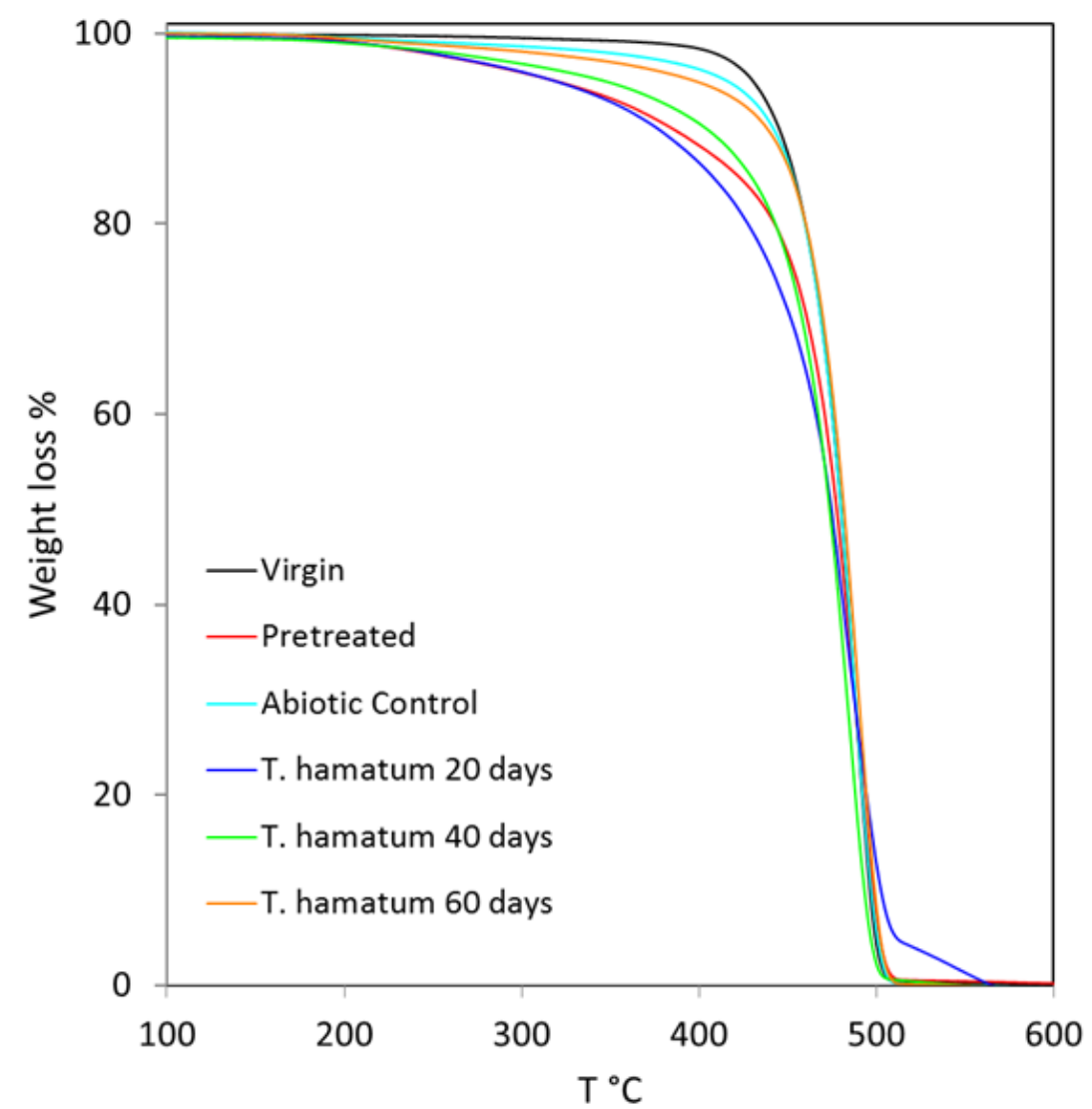

Figure 3. TGA curves of the $\gamma$-irradiation (200 kGy)/temperature $90{ }^{\circ} \mathrm{C}$ pretreated LLDPE exposed to biodegradation by T. hamatum for 20, 40, and 60 days, measured under nitrogen atmosphere $\left(10{ }^{\circ} \mathrm{C} \cdot \mathrm{min}^{-1}\right)$. Virgin LLDPE (black), pretreated LLDPE (red), pretreated LLDPE exposed to biodegradation by T. hamatum for 20 (blue), 40 (green), and 60 days (orange), abiotic control (cyan). 
Figure 4 shows the TGA curves of the pretreated LDPE films incubated for 60 day with T. hamatum and the corresponding abiotic control. The curves of the virgin and pretreated LDPE films are also shown for comparison. Those latter curves demonstrate that the main effect of the pretreatment was a lowering of the thermal stability of LDPE. This effect was probably due to the production of oxidized groups and cleavage reactions on the polymer chains. However, in contrast to the pretreated LLDPE (Figure 3), the 60-day incubation in the growth medium, either in the presence of the fungus or in its absence (abiotic control), did not increase the thermal stability of the LDPE films. This finding suggested that the UV irradiation did not generate polymer segments small enough to solubilize in the aqueous culture medium, nor did it generate functional groups enhancing the fungal attack.

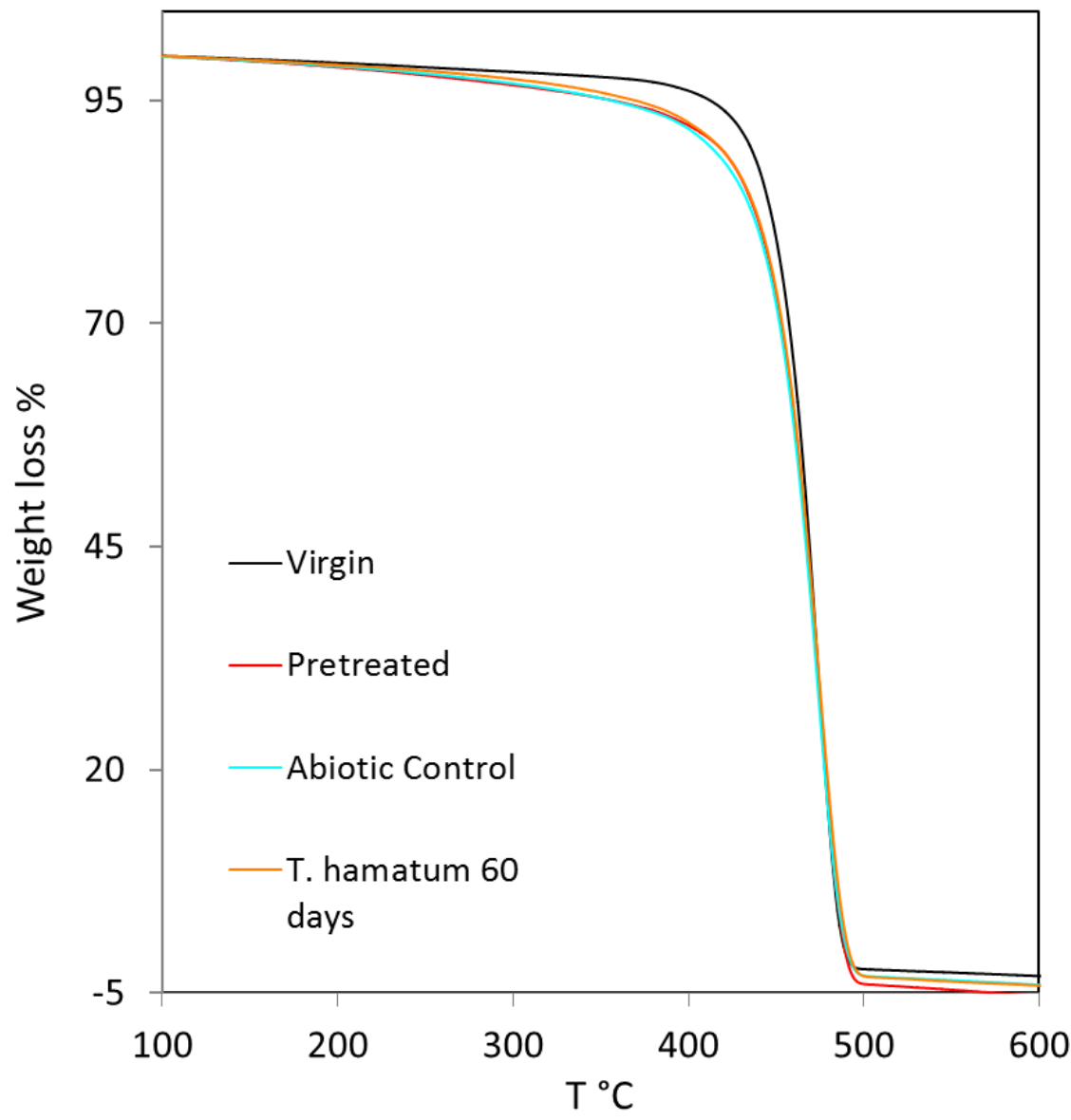

Figure 4. TGA curves of the UV irradiation (seven days)/temperature $60^{\circ} \mathrm{C}$ pretreated LDPE exposed to biodegradation by $\mathrm{T}$. hamatum for 60 days, measured under nitrogen atmosphere $\left(10^{\circ} \mathrm{C} \cdot \mathrm{min}^{-1}\right)$. Virgin LDPE (black), pretreated LDPE (red), pretreated LDPE exposed to biodegradation by T. hamatum for 60 days (orange), abiotic control (cyan).

\section{Conclusions}

A total of 26 and 18 bacterial and fungal strains colonizing weathered plastics in the environment were isolated, from which the fungus T. hamatum exhibited the largest weight loss-based biodegradation activities, which were confirmed, in the case of the pretreated LLDPE, by physicochemical analyses. However, even long-term contact with the plastics microenvironment resulting from the colonization of their surface, which was expected to lead to an all-round adaptation to these environmental conditions, provided strains with a generally low plastic-polymer degradation capacity, which documented the strong resistance of plastic polymers to biodegradation. The pretreatment of LLDPE and LDPE resulting in the formation of functional groups on the PE surface was able to slightly increase the degradability. 
Author Contributions: Conceptualization, K.M., Č.N., V.V.; Methodology, N.L., G.A., K.M., V.V., Č.N.; Investigation, Z.R., P.Š., M.S., G.A.; Resources, Z.R., P.Š.; Writing-Original draft preparation, Č.N., K.M.; Writing-Review and editing, G.A., N.L., V.V.; Project administration, F.F., K.M.; Funding acquisition, F.F., K.M. All authors have read and agreed to the published version of the manuscript.

Funding: This research was funded by EU programmes BIOCLEAN project No. 312100 and OPVK CZ.1.07/2.3.00/30.0019, by Institutional Research Concept RVO 61388971 provided by Ministry of Education, Youth and Sports of the Czech Republic, and by ERDF Institute of Environmental Technology-Excellent Research No. CZ.02.1.01/0.0/0.0/16_019/0000853.

Acknowledgments: The provision of plastic polymers by Versalis S.p.A. and Gruppo Fabbri Spa., Italy is gratefully acknowledged.

Conflicts of Interest: The authors declare no conflict of interest.

\section{References}

1. Kale, S.K.; Deshmukh, A.G.; Dudhare, M.S.; Patil, V.B. Microbial degradation of plastic: A review. J. Biochem. Tech. 2015, 6, 952-961.

2. Sivan, A. New perspectives in plastic biodegradation. Curr. Opin. Biotechnol. 2011, 22, 422-426. [CrossRef] [PubMed]

3. Ahmed, T.; Shahid, M.; Azeem, F.; Rasul, I.; Shah, A.A.; Noman, M.; Hameed, A.; Manzoor, N.; Manzoor, I.; Muhammad, S. Biodegradation of plastics: Current scenario and future prospects for environmental safety. Environ. Sci. Pollut. Res. 2018, 25, 7287-7298. [CrossRef] [PubMed]

4. Ali, M.I.; Ahmed, S.; Robson, G.; Javed, I.; Ali, N.; Atiq, N.; Hameed, A. Isolation and molecular characterization of polyvinyl chloride (PVC) plastic degrading fungal isolates. J. Basic Microbiol. 2014, 54, 18-27. [CrossRef] [PubMed]

5. Geyer, R.; Jambeck, J.R.; Law, K.L. Production, use, and fate of all plastics ever made. Sci. Adv. 2017, 3, e1700782. [CrossRef] [PubMed]

6. Briassoulis, D.; Babou, E.; Hiskakis, M.; Kyrikou, I. Degradation in soil behavior of artificially aged polyethylene films with pro-oxidants. J. Appl. Polym. Sci. 2015, 132, 42289. [CrossRef]

7. Fontanella, S.; Bonhomme, S.; Koutny, M.; Husarova, L.; Brusson, J.M.; Courdavault, J.P.; Pitteri, S.; Samuel, G.; Pichon, G.; Lemaire, J.; et al. Comparison of the biodegradability of various polyethylene films containing pro-oxidant additives. Polym. Degrad. Stab. 2010, 95, 1011-1021. [CrossRef]

8. Restrepo-Flórez, J.M.; Bassi, A.; Thompson, M.R. Microbial degradation and deterioration of polyethylene-A review. Int. Biodeter. Biodegr. 2014, 88, 83-90. [CrossRef]

9. Watanabe, T.; Ohtake, Y.; Asabe, H.; Murakami, N.; Furukawa, M. Biodegradability and degrading microbes of low-density polyethylene. J. Appl. Polym. Sci. 2009, 111, 551-559. [CrossRef]

10. Das, M.P.; Kumar, S. Microbial deterioration of low density polyethylene by Aspergillus and Fusarium sp. Int. J. Chem. Tech. Res. 2014, 6, 299-305.

11. Sindujaa, P.; Padmapriya, M.; Pramila, R.; Vijaya Ramesh, K. Bio-degradation of low density polyethylene (LDPE) by fungi isolated from marine water. Res. J. Biol. Sci. 2011, 6, 141-145.

12. Singh, J.; Gupta, K.C. Screening and identification of low density polyethylene (LDPE) degrading soil fungi isolated from polythene polluted sites around Gwalior city (M.P.). Int. J. Curr. Microbiol. App. Sci. 2014, 3, 443-448.

13. Singh, V.; Dubey, M.; Bhadauria, S. Microbial degradation of polyethylene (low density) by Aspergillus fumigatus and Penicillium sp. Asian J. Exp. Biol. Sci. 2012, 3, 498-503.

14. Nowak, B.; Pajak, J.; Drozd-Bratkowicz, M.; Rymarz, G. Microorganisms participating in the biodegradation of modified polyethylene films in different soils under laboratory conditions. Int. Biodeter. Biodegr. 2011, 65, 757-767. [CrossRef]

15. Czaczyk, K.; Bialas, W.; Myszka, K. Cell surface hydrophobicity of Bacillus spp. as a function of nutrient supply and lipopeptides biosynthesis and its role in adhesion. Pol. J. Microbiol. 2008, 57, 313-319.

16. Motta, O.; Proto, A.; De Carlo, F.; De Caro, F.; Santoro, E.; Brunetti, L.; Capunzo, M. Utilization of chemically oxidized polystyrene as co-substrate by filamentous fungi. Int. J. Hyg. Environ. Health 2009, 212, 61-66. [CrossRef]

17. Weiland, M.; Daro, A.; David, C. Biodegradation of thermally oxidized polyethylene. Polym. Degrad. Stab. 1995, 48, 275-289. [CrossRef] 
18. Arutchelvi, J.; Sudhakar, M.; Arkatkar, A.; Doble, M.; Bhaduri, S.; Uppara, P.V. Biodegradation of polyethylene and polypropylene. Indian J. Biotechnol. 2008, 7, 9-22.

19. Iiyoshi, Y.; Tsutsumi, Y.; Nishida, T. Polyethylene degradation by lignin-degrading fungi and manganese peroxidase. J. Wood Sci. 1998, 44, 222-229. [CrossRef]

20. Santo, M.; Weitsman, R.; Sivan, A. The role of the copper-binding enzyme-Laccase-In the biodegradation of polyethylene by the actinomycete Rhodococcus ruber. Int. Biodeter. Biodegr. 2013, 84, 204-210. [CrossRef]

21. Khan, I.; Ray Dutta, J.; Ganesan, R. Lactobacillus sps. lipase mediated poly (E-caprolactone) degradation. Int. J. Biol. Macromol. 2017, 95, 126-131. [CrossRef] [PubMed]

22. Park, C.; Kim, E.Y.; Yoo, Y.T.; Im, S.S. Effect of hydrophilicity on the biodegradability of polyesteramides. J. Appl. Polym. Sci. 2003, 90, 2708-2714. [CrossRef]

23. Cerdà-Cuéllar, M.; Kint, D.P.R.; Muñoz-Guerra, S.; Marqués-Calvo, M.S. Biodegradability of aromatic building blocks for poly (ethylene terephthalate) copolyesters. Polym. Degrad. Stab. 2004, 85, 865-871. [CrossRef]

24. Kleeberg, I.; Welzel, K.; VandenHeuvel, J.; Müller, R.J.; Deckwer, W.D. Characterization of a new extracellular hydrolase from Thermobifida fusca degrading aliphatic-aromatic copolyesters. Biomacromolecules 2005, 6, 262-270. [CrossRef]

25. Corti, A.; Muniyasamy, S.; Vitali, M.; Imam, S.H.; Chiellini, E. Oxidation and biodegradation of polyethylene films containing pro-oxidant additives: Synergistic effects of sunlight exposure, thermal aging and fungal biodegradation. Polym. Degrad. Stab. 2010, 95, 1106-1114. [CrossRef]

26. Tourova, T.P.; Sokolova, D.S.; Nazina, T.N.; Gruzdev, D.S.; Laptev, A.B. Phylogenetic diversity of microbial communities from the surface of polyethylene terephthalate materials exposed to different water environments. Microbiology 2020, 89, 96-106. [CrossRef]

27. Tien, M.; Kirk, T.K. Lignin peroxidase of Phanerochaete chrysosporium. Method. Enzymol. 1988, 161, $238-249$.

28. Mabrouk, A.M.; Kheiralla, Z.H.; Hamed, E.R.; Youssry, A.A.; Abd, A.A.A. Screening of some marine-derived fungal isolates for lignin degrading enzymes (LDEs) production. Agric. Biol. J. N. Am. 2010, 1, 591-599.

29. Archibald, F.S. A new assay for lignin-type peroxidases employing the dye Azure, B. Appl. Environ. Microbiol. 1992, 58, 3110-3116. [CrossRef]

30. Kelley, J.; Yaghmaie, P.A. Screening of fungal strains employed in the testing of plastics materials. Int. Biodeterior. Biodegr. 2001, 48, 84-93. [CrossRef]

31. Novotný, Č.; Malachová, K.; Adamus, G.; Kwiecień, M.; Lotti, N.; Soccio, M.; Verney, V.; Fava, F. Deterioration of irradiation/high-temperature pretreated, linear low-density polyethylene (LLDPE) by Bacillus amyloliquefaciens. Int. Biodeter. Biodegrad. 2018, 132, 259-267. [CrossRef]

32. Altschul, S.F.; Gish, W.; Miller, W.; Myers, E.W.; Lipman, D.J. Basic local alignment search tool. J. Mol. Biol. 1990, 215, 403-410. [CrossRef]

33. Wani, A.A.; Surakasi, V.P.; Siddharth, J.; Raghavan, R.G.; Patole, M.S.; Ranade, D.; Shouche, Y.S. Molecular analyses of microbial diversity associated with the Lonar soda lake in India: An impact crater in a basalt area. Res. Microbiol. 2006, 157, 928-937. [CrossRef] [PubMed]

34. White, T.J.; Bruns, T.D.; Lee, S.B.; Taylor, J.W. Amplification and direct sequencing of fungal ribosomal RNA genes for phylogenetics. In PCR Protocols: A Guide to Methods and Applications; Innis, M.A., Gelfand, D.H., Sninsky, J.J., White, T.J., Eds.; Academic Press: New York, NY, USA, 1990; pp. 315-322.

35. Gardes, M.; Bruns, T.D. ITS primers with enhanced specificity for basidiomycetes-Application to the identification of mycorrhizae and rusts. Mol. Ecol. 1993, 2, 113-118. [CrossRef]

36. Mezei, L.M.; Storts, D.R. Purification of PCR Products in PCR Technology: Current Innovations; Griffin, H.G., Griffin, A.M., Eds.; CRC Press: Boca Raton, FL, USA, 1994; p. 21.

37. Bochner, B. "Breathprints" at the microbial level. ASM News 1989, 55, 536-539.

38. Lee, B.; Pometto, A.L.; Fratzke, A.; Bailey, T.B. Biodegradation of degradable plastic polyethylene by Phanerochaete and Streptomyces species. Appl. Environ. Microbiol. 1991, 57, 678-685. [CrossRef]

39. Sheik, S.; Chandrashekar, K.R.; Swaroop, K.; Somashekarappa, H.M. Biodegradation of gamma irradiated low density polyethylene and polypropylene by endophytic fungi. Int. Biodeter. Biodegr. 2015, 105, 21-29. [CrossRef]

40. Brunner, I.; Fischer, M.; Rüthi, J.; Stierli, B.; Frey, B. Ability of fungi isolated from plastic debris floating in the shoreline of a lake to degrade plastics. PLOS ONE 2018, 13, e0202047. [CrossRef] 
41. Syranidou, E.; Karkanorachaki, K.; Amorotti, F.; Franchini, M.; Repouskou, E.; Kaliva, M.; Vamvakaki, M.; Kolvenbach, B.; Fava, F.; Corvini, P.F.-X.; et al. Biodegradation of weathered polystyrene films in seawater microcosms. Sci. Rep. 2017, 7, 17991. [CrossRef]

42. European Commission DGXI.E.3. The Behaviour of PVC in Landfill, Final Report February 2000, ARGUS in Association with University Rostock-Prof. Spillmann, Carl Bro als and Sigma Plan, S.A. Available online: http://ec.europa.eu/environment/waste/studies/pvc/landfill.pdf (accessed on 4 January 2017).

43. Liang, D.W.; Zhang, T.; Fang, H.H.P.; He, J. Phthalates biodegradation in the environment. Appl. Microbiol. Biotechnol. 2008, 80, 183-198. [CrossRef]

44. Giacomucci, L.; Raddadi, N.; Soccio, M.; Lotti, N.; Fava, F. Polyvinyl chloride biodegradation by Pseudomonas citronellolis and Bacillus flexus. New Biotechnol. 2019, 52, 35-41. [CrossRef] [PubMed]

45. Mersiowski, I.; Weller, M.; Ejlertsson, J. Fate of plasticised PVC products under landfill conditions: A laboratory-scale landfill simulation reactor study. Water Res. 2001, 35, 3063-3070. [CrossRef]

46. Reddy, M.M.; Deighton, M.; Gupta, R.K.; Bhattacharya, S.N.; Parthasarathy, R. Biodegradation of oxo-biodegradable polyethylene. J. Appl. Polym. Sci. 2009, 111, 1426-1432. [CrossRef]

(C) 2020 by the authors. Licensee MDPI, Basel, Switzerland. This article is an open access article distributed under the terms and conditions of the Creative Commons Attribution (CC BY) license (http://creativecommons.org/licenses/by/4.0/). 